\title{
The archaeology of early medieval violence: the mass grave at Budeč, Czech Republic
}

\author{
Ivo Štefan ${ }^{1, *}$, Petra Stránská ${ }^{2} \&$ Hana Vondrová ${ }^{1}$
}

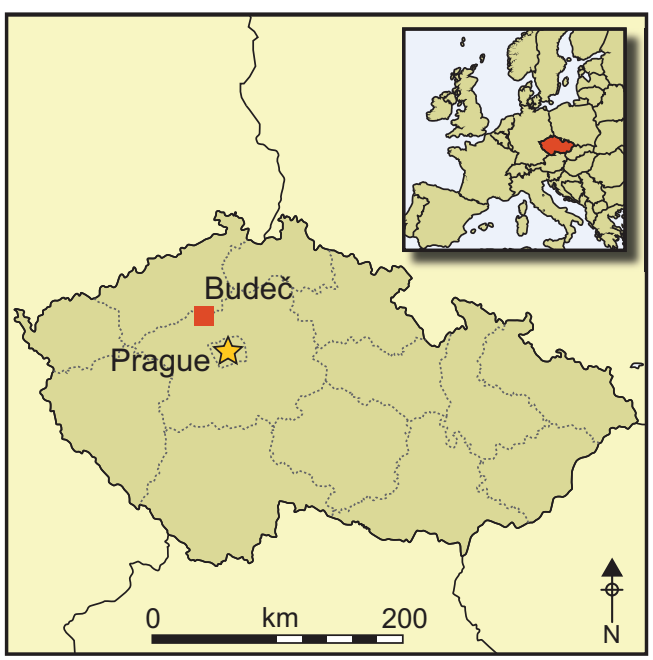

Widespread violence and military conflicts dominate many historical accounts of the Early Middle Ages in Europe, but archaeological evidence to corroborate such a picture has hitherto been scarce. Analysis of human remains from the Bohemian stronghold of Budec offers a unique insight into one such event: a wave of violence that probably followed the removal of Duke Wenceslas from power by his brother Boleslav $I$ in $A D$ 935. A mass grave near the hillfort holds mainly male burials that show numerous injuries sustained from sword blows, testifying to the human cost of this disturbance and demonstrating the structure and reality of early medieval violence.

Keywords: Czech Republic, Bohemia, Budeč, tenth-eleventh centuries, early medieval, mass grave, violence, warfare

\section{Introduction}

Military actions and violent events are among the leitmotifs of early medieval chronicles and annals in Europe, but unambiguous archaeological evidence remains surprisingly scant when compared to that from later periods. This is true even of long-lasting, large-scale military campaigns, and forces us to ask whether we would be able to identify these important events at all if we were restricted to material evidence alone. In 1982 a grave containing the remains of between 33 and 60 individuals was investigated close to the stronghold of Budeč, near Zákolany in central Bohemia. It represents one of the most extensive archaeological examples of large-scale violence dated to the Early Middle Ages in Europe, resembling, in many respects, the recently excavated mass grave at Ridgeway Hill near Weymouth in

1 Department of Archaeology, Faculty of Arts, Charles University, Prague, Celetná 20, 11636 Praha, Czech Republic (Email: stefanivos@seznam.cz)

2 Institute of Archaeology of Academy of Sciences of the Czech Republic, Letenská 4, 11801 Praha, Czech Republic

* Author for correspondence 
southern England (cf. Loe et al. 2014). In both cases, limitations in the available dating methods render attempts at linking the archaeology to specific historical events problematic. Multidisciplinary analyses of mass graves can, however, offer unique insights into the nature of early medieval violence that are not provided by written sources. Moreover, this bloody event probably changed the internal organisation of the Budeč stronghold and influenced the funerary rites of the survivors.

\section{Historical and archaeological background}

Early medieval Bohemia receives no mention in written sources before the ninth century. In $\mathrm{AD} \mathrm{872,} \mathrm{the} \mathrm{Annals} \mathrm{of} \mathrm{Fulda} \mathrm{refer} \mathrm{to,} \mathrm{among} \mathrm{other} \mathrm{regional} \mathrm{Bohemian} \mathrm{dukes,} \mathrm{the}$ first-known member of the Přemyslid dynasty, Bořivoj I, who accepted baptism and built the first churches in Bohemia. Initially, the Přemyslids controlled only a small region around Prague. In AD 935, the ruling Přemyslid, Wenceslas, was murdered by his brother Boleslav and his retainers. This event is usually regarded as an important turning point in early Bohemian history. Shortly after his accession, Boleslav I (ruled AD 935-972) renounced the Franks and began to centralise power in Bohemia and expand into other regions. The basic structures and ideology of the Christian Přemyslid monarchy were thus created over the course of the tenth century (Charvát 2010; Kalhous 2012; Berend et al. 2013).

An early stage in this process is marked in the second half of the ninth century and the first half of the tenth century by the emergence of a great concentration of fortified settlements in central Bohemia. Following the consolidation of power by the first Přemyslids, Prague, with its central location, had become the family's main residence, but at least 10 additional extensive and massively fortified strongholds came into existence. Tenth-century legends name some of them as the residences of non-ruling members of the Přemyslid dynasty and their retinues (Sláma 1988; Varadzin 2011).

The hillfort of Budeč, about 16km north-west of Prague, was one of the most important of these centres, as is evidenced by the tenth-century hagiographical literature (especially by so-called Legenda Christiani) from the 990s, which mentions the founding of the local church of St Peter by Duke Spytihněv I (ruled AD 895-915). Budeč is most often mentioned in connection with Duke Wenceslas, who later became a saint, who reportedly received his basic education from a local priest there in his youth sometime before AD 925. The site is not mentioned in later written sources, and a thirteenth-century report on the church did not mention Budeč as a stronghold, which suggests that it was already abandoned by that time (Sláma 1988: 12-13; Bartošková 2010: 87-90).

Systematic research by the Institute of Archaeology of the Academy of Sciences in Prague was carried out at several sites in and around Budeč between 1972 and 1990. Detailed analysis of the results allows us to reconstruct the basic stages of development for both the site and the surrounding area (for a summary, see Bartošková 2010).

Budeč was built on an extensive elevated spur (Figure 1). The beginnings of unbroken early medieval settlement can be traced back to the late eighth or early ninth century AD. The construction of the first fortification, however, which delimited a 3.5ha compound (the so-called acropolis), dates to the end of the ninth century. An external compound (bailey) was

(C) Antiquity Publications Ltd, 2016 


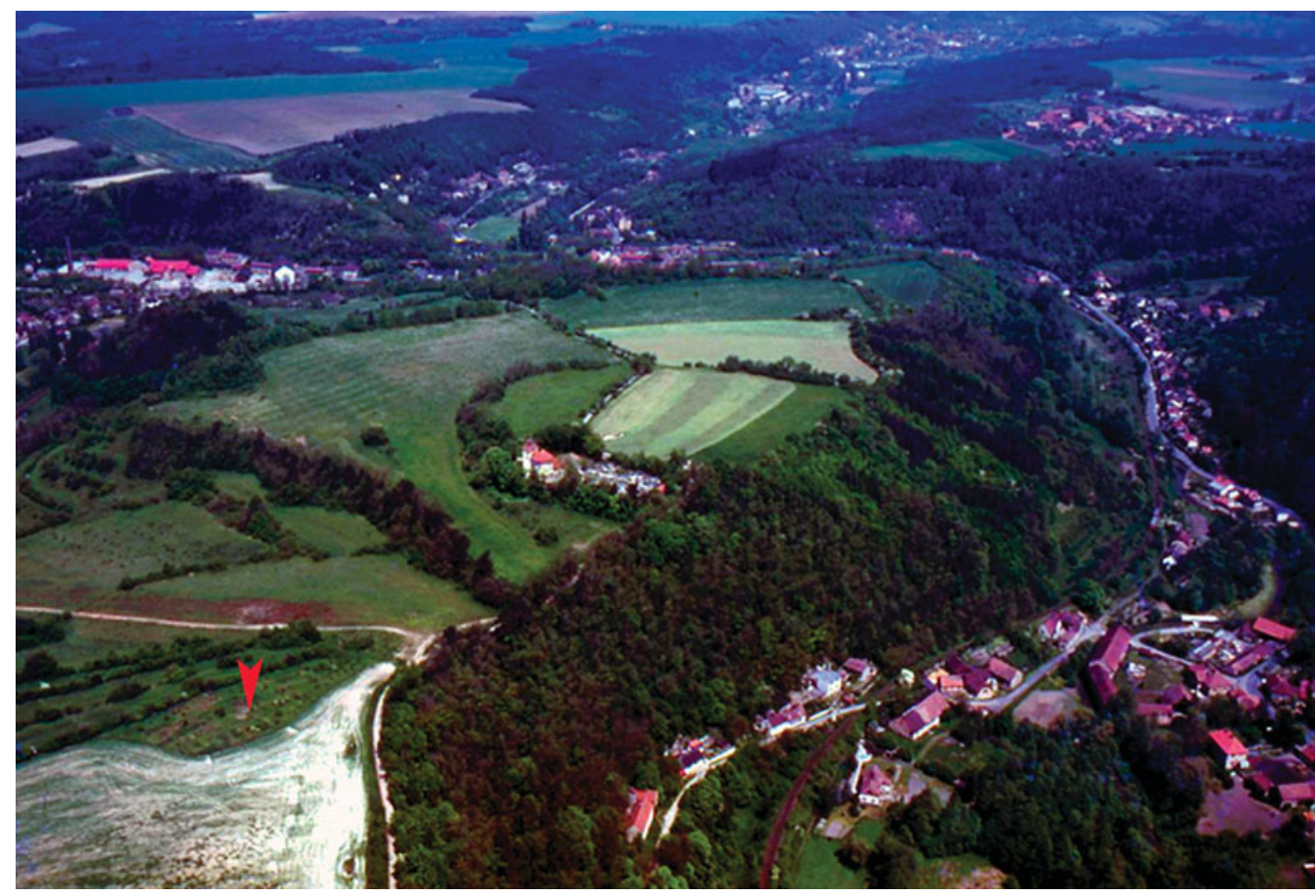

Figure 1. Aerial view of the fortified settlement at Budeč; the arrow marks the position of the mass grave; the church of St Peter and St Paul at the acropolis of the stronghold is in the middle (photograph by M. Gojda).

fortified not long afterwards, increasing the area of the stronghold to $15.2 \mathrm{ha}$. The possible existence of two more fortified baileys cannot be ruled out (Figure 2), but neither has yet been investigated.

Both historical texts and archaeological evidence indicate that the decades between the later ninth and mid tenth centuries mark the most important period in the history of Budeč, when it fulfilled not only military but also sacral and residential functions. A rectangular structure enclosed by a palisade, interpreted as the ducal residence, was discovered within the internal compound. The still-standing rotunda of St Peter's church was situated in what was originally its south-west corner. It was not long after this period that burials began to be made around the church. The low number of burials (56) and the high-status jewellery in several graves testify to the elite character of the cemetery. Another burial ground with finds of high-status jewels and spurs to the north of the stronghold was also partly investigated (Figure 2).

Determining the population of Budeč and reconstructing its social and economic structure proved problematic owing to the limited extent of the excavation. The Anglo-Saxon Burghal Hidage, written in the early tenth century, counts one defender per $1.3 \mathrm{~m}$ of wall in an ideal case (Baker \& Brooks 2013: 33), which would mean more than a thousand defenders would have been required for Budeč's $1400 \mathrm{~m}$-long outer wall. Although we regard this figure as unrealistic, Budeč certainly would have had at least several hundred inhabitants in this period, with the military garrison comprising a substantial component.

(C) Antiquity Publications Ltd, 2016 


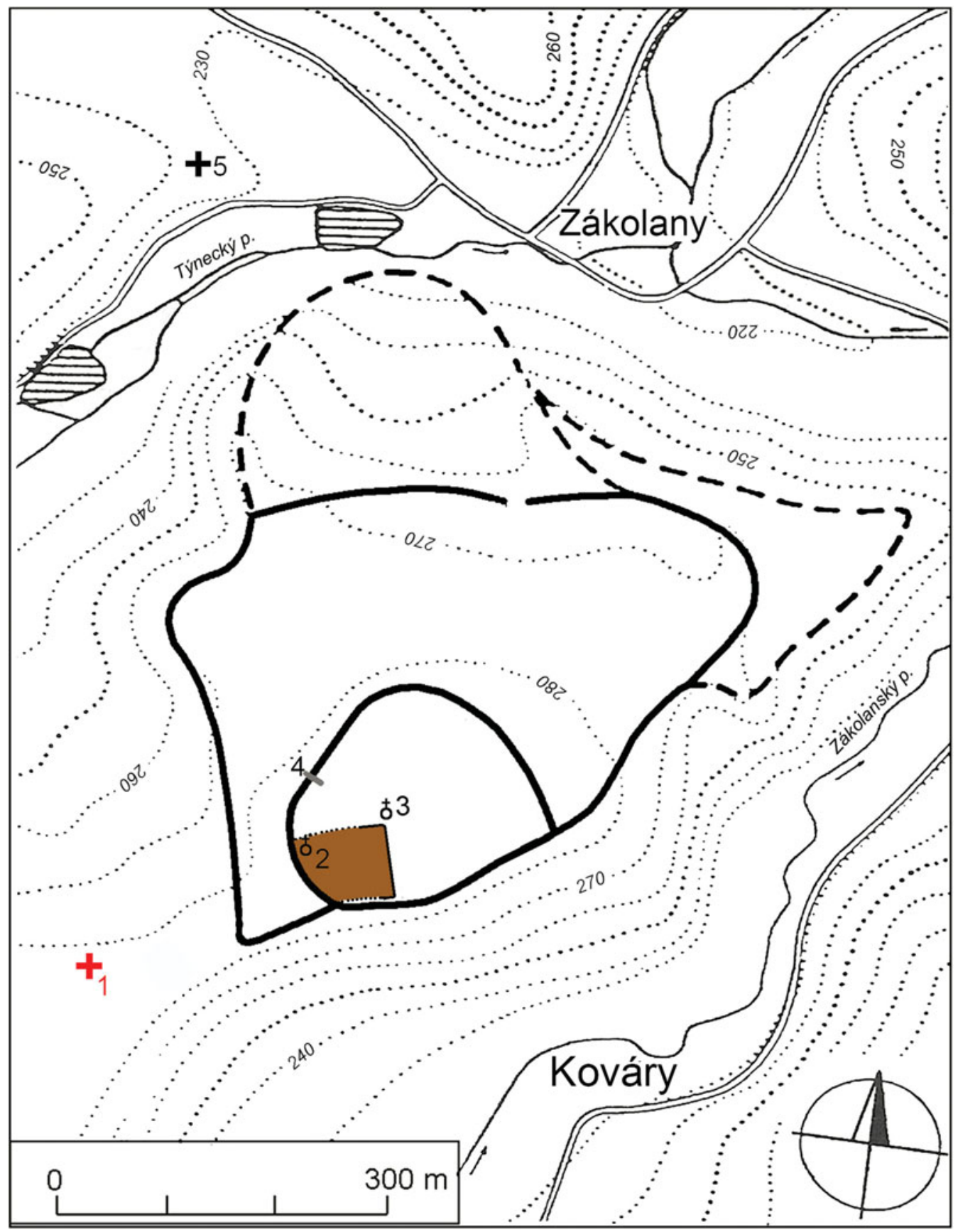

Figure 2. Plan of the Budeč stronghold; the continuous line marks the proven early medieval fortification, the broken line the unproven. 1) The mass grave and burial ground in the locality Na Týnici; 2) Sts. Peter and Paul church in the NW corner of the 'ducal court' (grey) situated on the edge of the acropolis; 3) Virgin Mary church in the centre of the acropolis; 4) a cut through the earthwork between the acropolis and the first bailey with traces of fire; 5) Zákolany burial ground.

(C) Antiquity Publications Ltd, 2016 
Archaeological research has identified a number of related changes that took place during the second third of the tenth century at several places within the stronghold. North of St Peter's church, the first stage of the acropolis rampart was destroyed in a major fire (Figure 2: 4). The whole rampart was subsequently rebuilt and significantly extended. West of St Peter's church, this second phase of fortification overlapped part of the churchyard, where burial activities ceased altogether until the twelfth century. In the second third of the tenth century, burials were moved to the church of the Virgin Mary, built in the centre of the acropolis in this period. Finally, the palisade delimiting the so-called ducal residence was demolished in this period (Bartošková 2011). The importance of Budeč, as with that of several other central Bohemian strongholds, gradually declined in the eleventh century, and the settlement was abandoned in the second half of the eleventh century.

\section{Mass burial of massacred men and a burial ground of women and children}

Archaeological excavation at ' $\mathrm{Na}$ Týnici', approximately $150 \mathrm{~m}$ south-east of the stronghold, took place from 1982-1988 under the guidance of Ivan Krutina (Figure 2: 1). A total area of $1025 \mathrm{~m}^{2}$ was investigated, but as has recently been observed, the excavations unfortunately did not meet all of the standards expected today (Štefan \& Krutina 2009).

A small unfortified settlement developed in this area in the second half of the ninth century, but only existed for a brief period. Several sunken structures dug into the bedrock were identified. These became filled with silt when its inhabitants left, apparently in peaceful circumstances, sometime around the beginning of the tenth century. Subsequently, a pit 2.7 $\times 2.9 \mathrm{~m}$ and around $1.2 \mathrm{~m}$ deep was dug in the backfill of one of these earlier structures, a rectangular building with a sunken floor measuring $3.8 \times 3.3 \mathrm{~m}$ in the centre of the abandoned settlement. In a single episode, parts of human bodies and a great number of individual bones were deposited in it, with evidence for advanced soft tissue decomposition by the time of deposition (Figures $3 \& 4$ ). Tooth marks (dog or fox) identified on the bones suggest that the bodies had remained unburied for some time prior to their deposition. The bones of at least one individual show traces of burning. The largest concentration of skeletal remains was in the upper layer, while stones and sandy soil were better represented in the lower deposits. Overlying the bone deposit was a separate female skull with eight $S$-shaped temple rings in situ, typical of tenth- to twelfth-century jewellery from Bohemia. No other artefacts belonging to the dead were recovered from the pit. Unfortunately, the positions of the individual bones were not planned during the excavation, restricting subsequent attempts at bioarchaeological analysis. The basic determination of the set was carried out by Miroslava Blajerová (1992). The new osteological analysis has concentrated primarily on the evidence of injury and on improving the determination of sex and age (Stloukal \& Vyhnánek 1976; Lovejoy 1985; Brooks \& Suchey 1990; Buikstra et al. 1994; Walrath et al. 2004; Schmitt 2005).

The remains of between 33 and 60 individuals were deposited in the pit. The minimum number is based on the number of complete or almost complete skulls, whereas the maximum number is determined from the fragments of other cranial bones, jaws and elements of post-cranial skeleton. The higher figure is, accordingly, considered more 

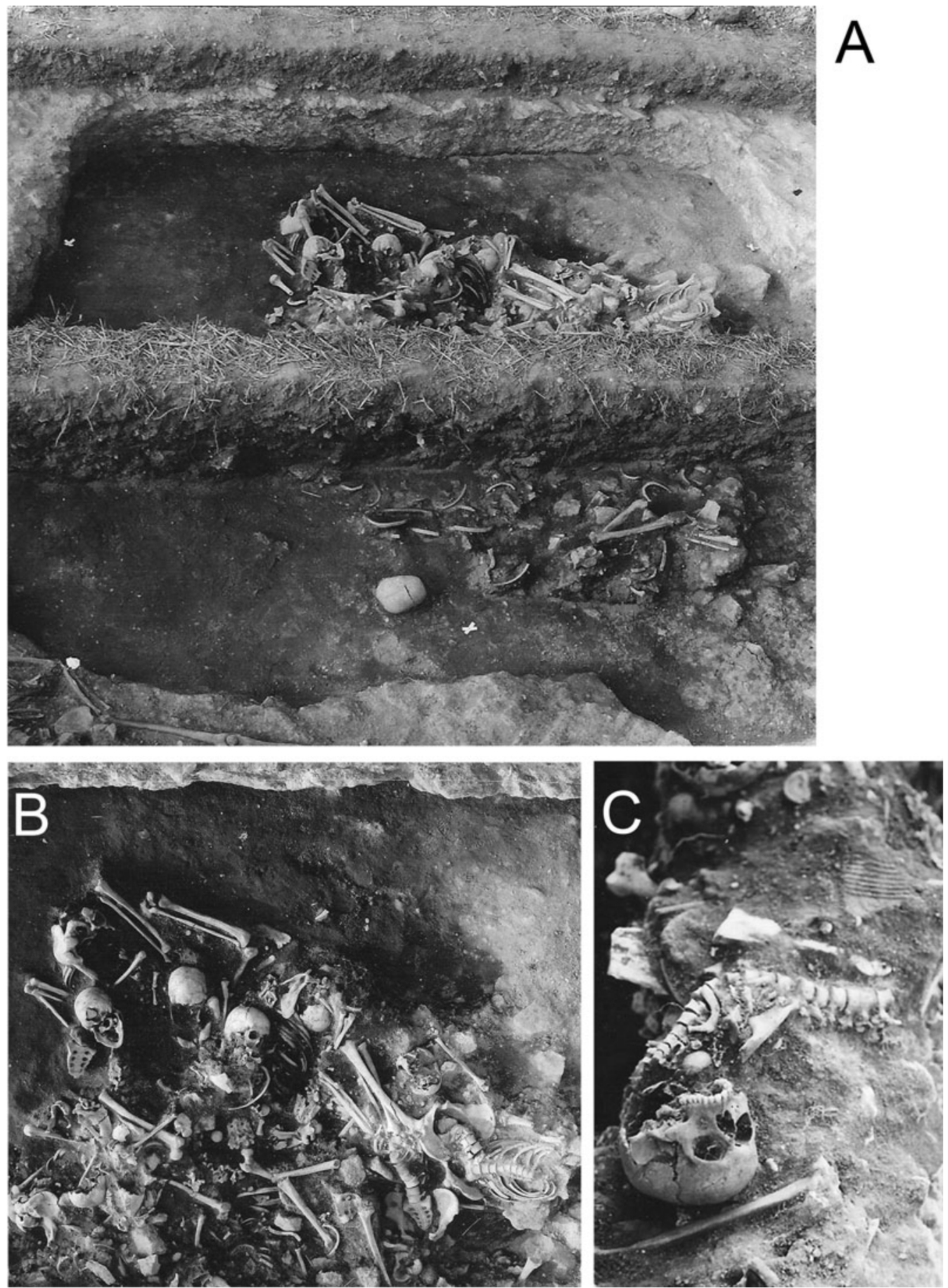

Figure 3. The mass grave during excavation: A) view from the south-east; B) detail of the deposit of bones; C) preserved part of the skeleton (photograph by Ivan Krutina).

(C) Antiquity Publications Ltd, 2016 


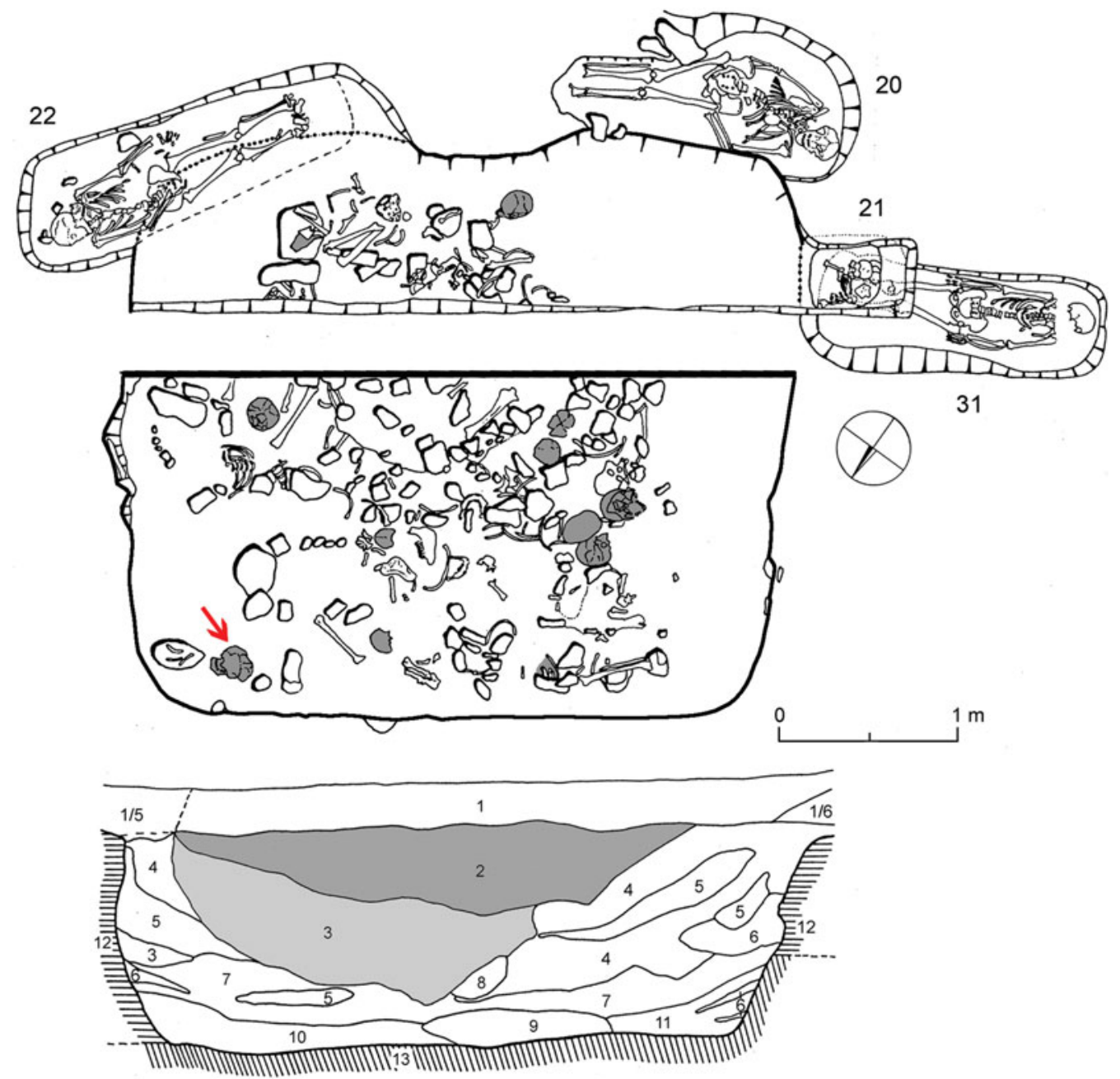

Figure 4. The ground plan and the profile of the mass grave deposited in a vanished sunken-floored building; the arrow marks the female skull with eight S-shaped temple rings. Layers in the profile: 2 \& 3: mass grave; 4-11: backfill of the sunken-floored building; 12 \& 13: undersoil.

accurate. Both the sex and age structures of the buried individuals represent a very particular demographic. Sex can be reliably determined for just 24 skulls, of which only one showed feminine sexual traits. All of the 18 extant pelvic bones also belong to men. The majority of the skulls belong to young adult men (20-40 years of age; Table 1). The prevalence of above-average to tall men with mostly medium-massive to massive muscular attachments on the skeleton is noteworthy. Frequent flattening of the tibiae has been observed, which demonstrates a greater pressure from the calf muscles and popliteus (Kelley \& Angel 1987). Under prolonged physical load the internal bone structure will be rebuilt and the external shape is changed (Bartoníček \& Heřt 2004: 65-82). In addition to the impact of the external conditions, however, genetic influences are involved in the change of the bone morphology (Ruff et al. 2006). The pathological development of the sacra suggests that several of the 
Table 1. Age structure of the dead buried in the mass grave based on skulls and skull fragments. The number of skull fragments may not correspond to the number of individuals.

\begin{tabular}{lccc}
\hline Age & Skulls & Skull fragments & Total \\
\hline & & & \\
Approximately 20-29 years & 11 & 2 & 13 \\
Approximately 30-39 years & 1 & 0 & 1 \\
Approximately 20-39 years & 12 & 23 & 35 \\
Approximately 40-49 years & 6 & 0 & 6 \\
Approximately 50-59 years & 1 & 1 & 2 \\
Approximately 40-59 years & 1 & 0 & 1 \\
Approximately 60 years and older & 1 & 1 & 2 \\
\hline
\end{tabular}

individuals were related. The cranial indices are not exceptional when compared to the domestic population surveyed from other contemporary burial grounds (Blajerová 1992; Stránská 2009). The crania of the men are, however, on average the longest and among the highest out of all comparable groups. Stable isotope analysis, which might reveal the geographic origin of the buried individuals and their living conditions, has not yet been undertaken.

New palaeopathological analysis indicates that most of the men died a violent death, and had suffered predominantly cranial and spinal injuries. Slash wounds, probably caused by swords - an important weapon of elite tenth-century warriors in Central Europe (cf. Wieczorek \& Hinz 2000)—are the most numerous. The character of the injuries suggests that some individuals were decapitated, but the exact number is difficult to determine because of the disarticulated condition of the skeletons. In at least one case, however, the head had not been completely severed (Figure 3C). From the cervical vertebrae, we determined that between 10 and 24 victims were decapitated (Figures $5 \& 6$; Table 2). Other evidence indicative of decapitation includes cut marks on the external occipital tuberosities, the mastoid processes of the temporal bone, and the condylar process and other cut marks elsewhere on the lower jaw. Blows by sharp implements to the back may also have hit the thoracic and lumbar vertebrae. Slash wounds (in 20 cases) and depressed fractures (in 5 cases) caused by stabbing weapons were also observed on the parietal bones. Crucially, the typical evidence of defensive injuries, 'parry fractures', most commonly located on the forearm and the humerus, are missing completely, except in a single case (e.g. Fiorato et al. 2000: 93; Kjellström 2005: 41). The distribution of the injuries thus indicates that the victims did not die in hand-to-hand combat on relatively equal terms. In some cases, decapitation might have been preceded by other blows. Healed slash wounds, however, were also observed on five skulls and one shin bone (Table 2; Figure 5), which indicates that at least some of the men had previous experience of combat. The bodies were apparently stripped of clothing, at least by the time of their burial.

The massacred men found at $\mathrm{Na}$ Týnici were not the only people buried below the walls of Budeč: 114 graves containing 119 individuals were examined in the area around the mass grave (Figure 7). In addition to these 114 graves, a number of other graves lie beyond the excavated area, and an overall total of 150 graves can be estimated (Štefan \& Krutina (C) Antiquity Publications Ltd, 2016 


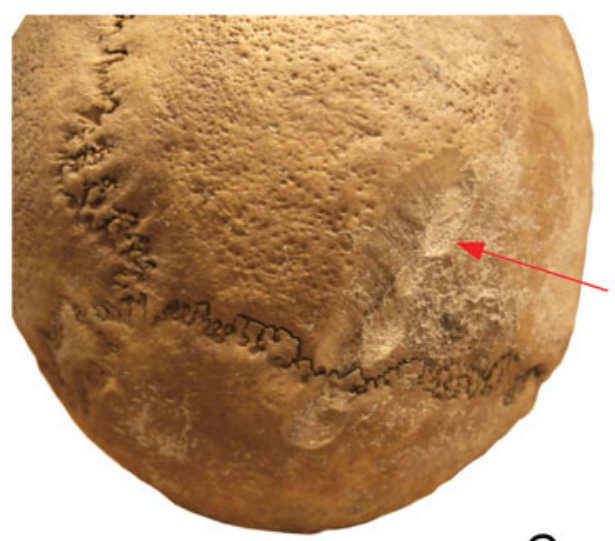

A
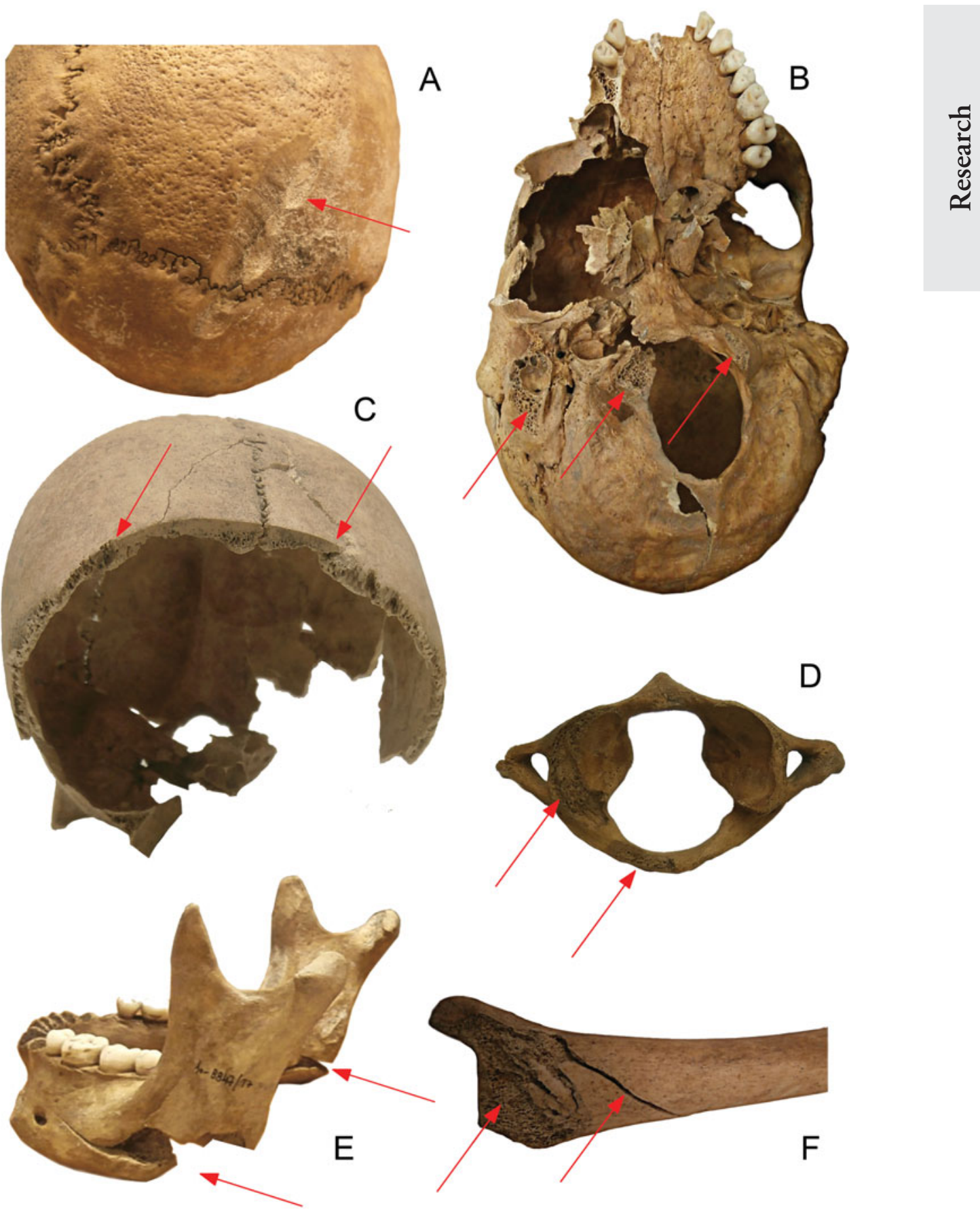

Figure 5. The examples of injuries identified on bones: A) healed sharp-force injury, tangential right parietal and occipital bone; B) sharp-force injury on right processus mastoideus of temporal bone and condylus occipitalis of occipital bone, interpreted as evidence of decapitation; C) sharp-force trauma, led frontally through both parietal bones; D) cut-off on atlas, possible decapitation; E) cuts on mandible, indicating a possible decapitation; F) sharp-force injury and crack on distal head of tibia.

(C) Antiquity Publications Ltd, 2016 

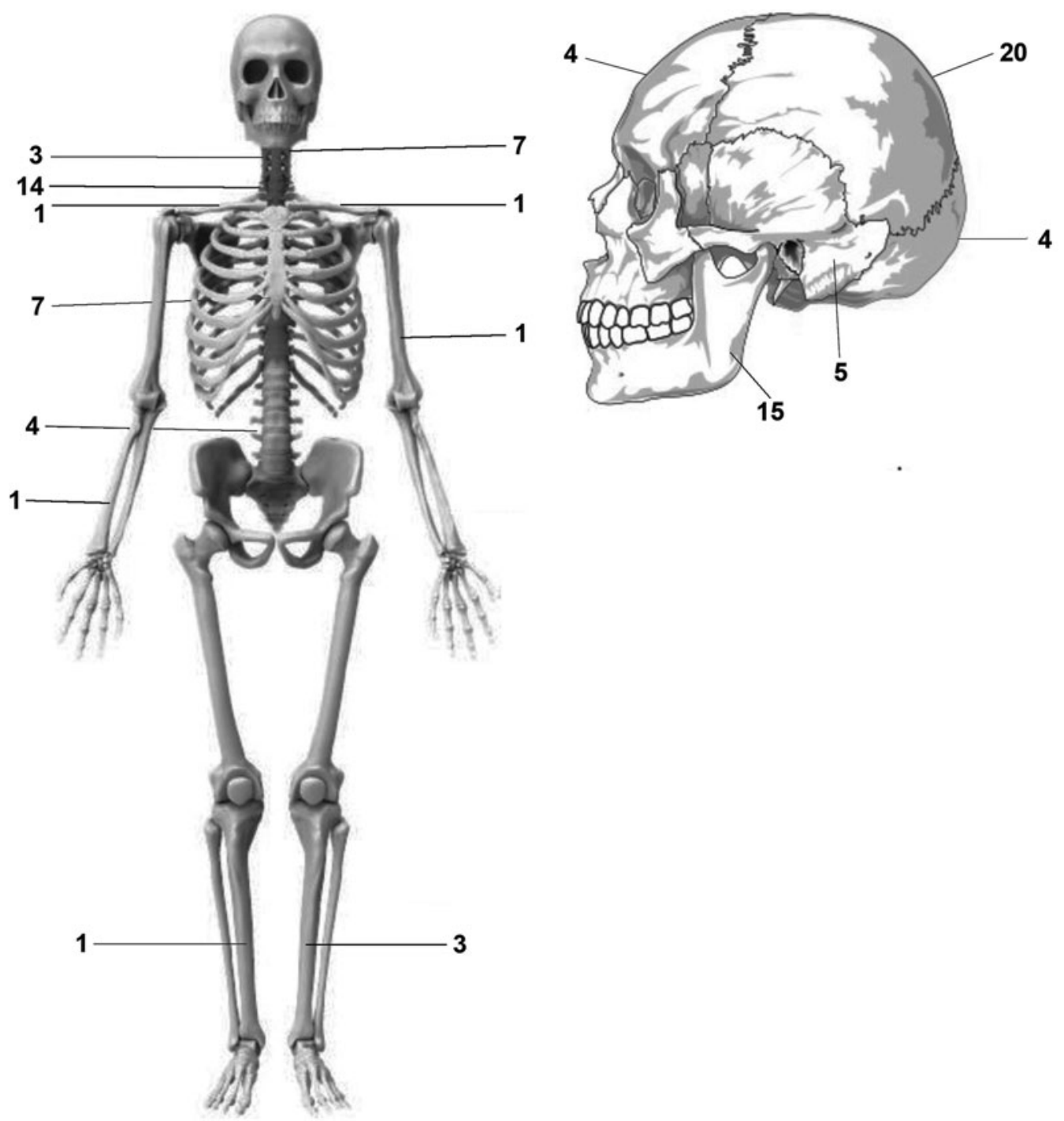

Figure 6. The distribution of the slash wounds on the post-cranial skeleton and skull suffered perimortem (unhealed injuries); the left and right sides are not distinguished for paired cranial bones; the numbers refer to the frequency of each injury, as documented in Table 2.

2009; Stránská 2009). The dead were buried in separate grave cuts and there are no traces of injury on their bones. The average age of adults was 48.4 years for men and 44.4 years for women, leading us to believe that these people died from natural causes. The unbalanced ratio of women to men is remarkable: 61 skeletons belonged to children, 34 to women and only 9 to men. Although the sex of a further 15 adults remained undetermined, it is improbable that they would have all been men. This mortality profile does not represent a normal community. The differences between the metric and morphological characteristics

(C) Antiquity Publications Ltd, 2016 


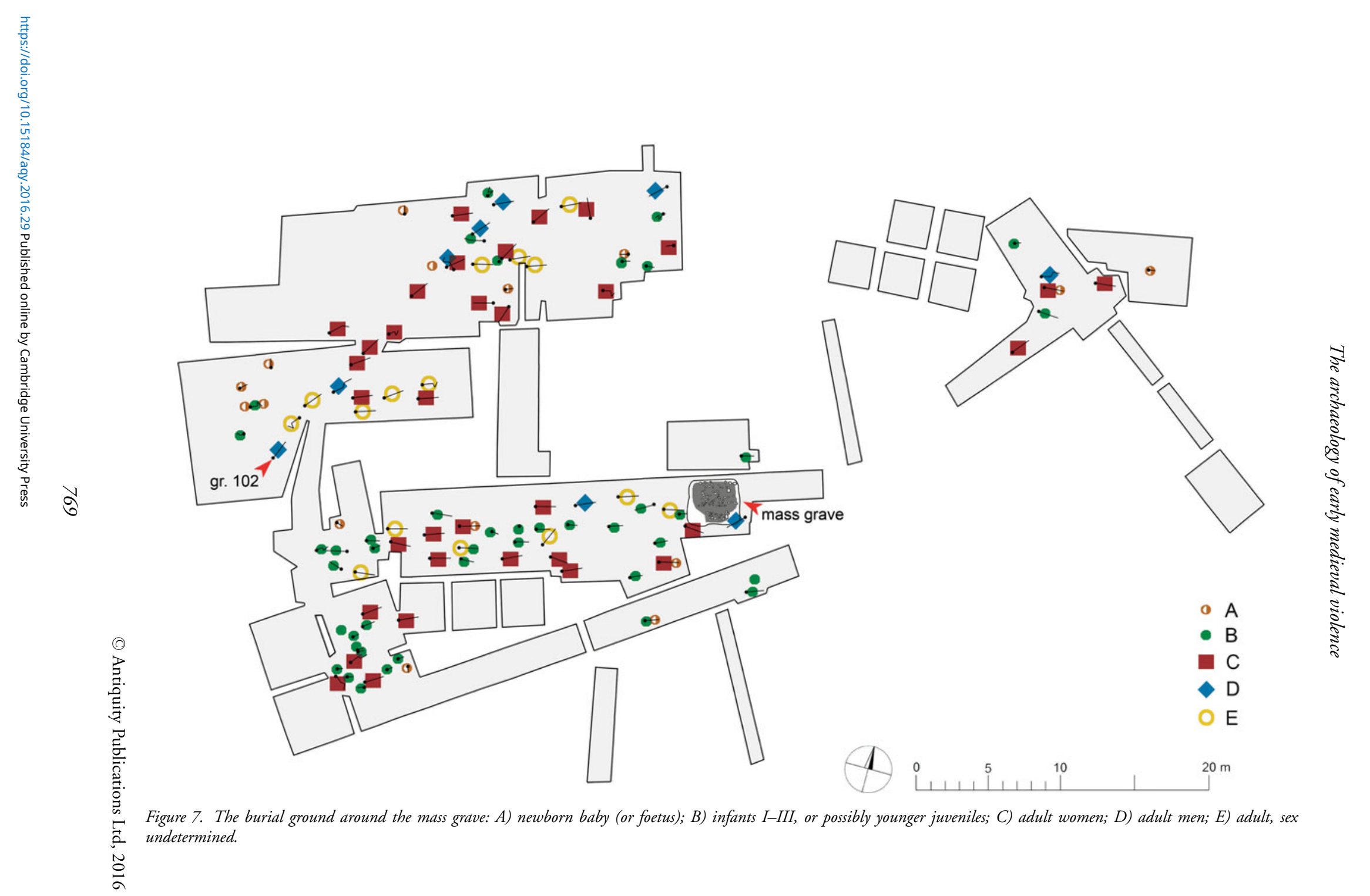

Research 
Table 2. Slash wounds, depressed fractures and linear fractures suffered perimortem (unhealed) and $(*)$ antemortem (healed); cranial skeleton injuries are shown in light grey and post-cranial skeleton injuries in dark grey.

\begin{tabular}{|c|c|c|c|c|c|c|c|c|}
\hline \multirow{2}{*}{$\begin{array}{c}\text { Type of } \\
\text { bone }\end{array}$} & \multirow{2}{*}{$\begin{array}{c}\text { Overall } \\
\text { no. of } \\
\text { bones in } \\
\text { the set }\end{array}$} & \multicolumn{3}{|c|}{ Side determination } & \multirow{2}{*}{$\begin{array}{l}\text { Overall no. } \\
\text { of bones } \\
\text { with injury }\end{array}$} & \multirow[b]{2}{*}{ Right } & \multirow[b]{2}{*}{ Left } & \multirow[b]{2}{*}{ Undetermined } \\
\hline & & Right & Left & Undetermined & & & & \\
\hline Frontal bone & 26 & - & - & - & $4 / 2^{*}$ & - & - & - \\
\hline $\begin{array}{c}\text { Parietal } \\
\text { bone }\end{array}$ & 68 & 29 & 30 & 9 & $27 / 4^{*}$ & $12 / 3^{*}$ & $6 / 1^{*}$ & 9 \\
\hline $\begin{array}{l}\text { Occipital } \\
\text { bone }\end{array}$ & 26 & - & - & - & $4 / 1^{*}$ & - & - & - \\
\hline $\begin{array}{l}\text { Temporal } \\
\text { bone }\end{array}$ & 48 & 23 & 25 & - & 5 & 3 & 2 & - \\
\hline Lower jaw & 26 & - & - & - & 15 & - & - & - \\
\hline Atlas & 16 & - & - & - & 7 & - & - & - \\
\hline Axis & 11 & - & - & - & 3 & - & - & - \\
\hline $\begin{array}{l}\text { Cervical } \\
\text { vertebrae } \\
\text { C3-C7 }\end{array}$ & 83 & - & - & - & 14 & - & - & - \\
\hline $\begin{array}{l}\text { Thoracic } \\
\text { vertebrae }\end{array}$ & 155 & - & - & - & 7 & - & - & - \\
\hline $\begin{array}{l}\text { Lumbar } \\
\text { vertebrae }\end{array}$ & 74 & - & - & - & 4 & - & - & - \\
\hline Collarbone & 37 & 20 & 17 & - & 2 & 1 & 1 & - \\
\hline Humerus & 28 & 14 & 14 & - & 1 & - & 1 & - \\
\hline Radius & 51 & 29 & 22 & - & 1 & 1 & - & - \\
\hline Shin bone & 52 & 27 & 25 & - & $3 / 1^{*}$ & 1 & $2 / 1^{*}$ & - \\
\hline
\end{tabular}

of the skeletons of the men buried in the mass grave and those in the ordinary graves are noteworthy. The latter were characterised by significantly less robustness, less-developed muscle attachments and lower height. The values of cranial indices were also different. Compared to the mass grave, none of the male skulls in the cemetery were above average in length and height (Blajerová 1992; Stránská 2009).

Additional insights may be gained through comparison with other contemporary cemeteries in Bohemia. The typical burial practice involved laying the dead on their back with an east-west orientation, arms alongside the body. At Na Týnici this practice was only documented in some cases. A third of the dead were buried in a variety of different orientations (Figure 7) and 13 per cent of them were found crouched on their side or in the prone position. This position had clear negative connotations: only those who, for whatever reason, were deemed to be on the edge of the social spectrum were buried in this way (Štefan 2009). Only 35 per cent of the buried were accompanied by grave goods and in most cases these were ordinary items of no special value. There were no weapons or military equipment, suggesting that the graveyard did not belong to a local elite.

A terminus post quem for the burial of the victims of the massacre is provided by pottery fragments from the backfill of the sunken-floored building into which the mass grave was (C) Antiquity Publications Ltd, 2016 
Table 3. AMS radiocarbon dates of three left femora undertaken by Poznań radiocarbon laboratory, calibrated with Oxcal 4.2.

\begin{tabular}{llll}
\hline Laboratory number & Context & Age (BP) & Age range (cal AD) \\
\hline \multirow{2}{*}{ Poz-11601 } & & & \\
& Mass grave & $1170 \pm 30$ & $780-900(68.2 \%)$ \\
Poz-11600 & & & $770-970(95.4 \%)$ \\
& Mass grave & $1130 \pm 30$ & $910-970(53.6 \%)$ \\
Poz-11655 & & & $810-990(94.5 \%)$ \\
& Grave 102 & $1125 \pm 30$ & $910-975(55.5 \%)$ \\
& & & $860-1000(92.4 \%)$ \\
\hline
\end{tabular}

cut. These date between the end of the ninth century and the first third of the tenth century $\mathrm{AD}$. More recent pottery, of a kind that started to be produced in central Bohemia around AD 930, was only found in the upper part of the backfill among the bones. Small S-shaped temple rings similar to those associated with the female skull were current in Bohemia from approximately the beginning of the tenth century to the middle of the eleventh century. Radiocarbon dating of two thigh bones, although slightly divergent, would be consistent with death before the end of the tenth century AD (Table 3). Taken together, these indications lead us to propose that the massacre took place within the period $\mathrm{AD}$ 930-990.

The chronological relationship between the mass grave and the surrounding burials remains uncertain because there is no stratigraphical relationship between them, and the grave goods are not chronologically specific. Using associated finds of personal ornaments, the oldest of the surrounding graves are dated to $c$. AD 900-950. According to this evidence, burial in this locality ended in the early eleventh century at the latest, an estimate that is supported by radiocarbon dating of grave 102 (Table 3). The mass grave and the surrounding burials are therefore probably interrelated, but this hypothesis remains untested. The most probable scenario is that most of the women and children buried in the ordinary graves were relatives of the massacred men. The prevalence of women, the poor grave goods and the number of anomalies in the deposition of the bodies is consistent with this theory. This group might have lost their standing in society, or indeed their safety within the community as a consequence of the massacre. The identity of the men buried in the ordinary graves has not yet been determined, but it appears that they too were not members of the local elite at the time of their burial.

\section{Discussion}

There is no doubt that the violent death of up to 60 young men was connected with the struggle for control of Budeč as an important power centre in Bohemia during the tenth century. If we accept the hypothesis that the mass grave and the surrounding burial ground belonged to a single community, we can regard the killed men as members of the stronghold's garrison, rather than its conquerors. The different metric characteristics of their skulls might, however, indicate a non-native origin, perhaps as foreign warriors in the service of the Duke of Bohemia who came from abroad in their lifetime (cf. Kara 1992 for Poland; 
and Price et al. 2011 for Denmark). According to a late tenth-century legend called Legenda Christiani devoted to Bohemian saints, retainers with non-Slavic (possibly Scandinavian) names worked in the service of the first Přemyslids.

The discovery that at least some of the individuals were decapitated is made even more surprising by the fact that, in contrast to England (Reynolds 2009), the oldest execution cemeteries in Central Europe (including Germany) date only to the High Middle Ages. This impression may derive from the fact that the remains of those who had been executed were treated differently. The narrative sources of the Early Middle Ages, which were usually authored by churchmen, rarely pay attention to the fate of the defeated (Halsall 2003: 210-14). It is difficult, therefore, to judge whether mass executions and massacres were a customary outcome of military and political conflicts, or rather an exceptional occurrence. Of the examples where they are known to have resulted from conflicts, the execution of members of the Alamannian aristocracy in Cannstatt by the Franks in AD 746 can be cited (Zotz 1999), but perhaps the biggest massacre of the Early Middle Ages took place near Verdun in AD 782, where 4500 Saxons were allegedly executed in a single day at Charlemagne's command, although the extremely high number of victims reported at Verdun is the subject of ongoing discussion (Hägermann 2010: 214-17). Over a century later, when the Frankish emperor Henry I conquered Gana, the main stronghold of the Slavic tribe the Daleminzi, in AD 929, all adult defenders were slaughtered (Bachrach 2013: 327). Just as today, the aim of such mass executions was to neutralise one's opponents, both in reality and symbolically.

Although the massacre at Budeč would certainly have resonated in collective memory for some time, we can find no reference to it in the historical texts. The strongly selective and purposive character of the extant sources must, however, be acknowledged, and could explain why many violent events seem completely to have escaped the interest of their authors. Moreover, it is often impossible to identify the precise locality of conflicts that are discussed in the documentary sources, let alone assess their extent and character (cf. Stefan \& Krutina 2009: 206).

Accounts of Bohemia's external military conflicts in the second third of the tenth century relate exclusively to attacks by the East Frankish Empire. Henry I undertook a major military campaign in Bohemia in AD 929, immediately after his defeat of the Daleminzi. He marched directly towards Prague, and the ruling duke, Wenceslas, seems to have surrendered to him without much resistance (Bachrach 2013). In AD 950, the army of Otto I besieged a recently established castle somewhere in Bohemia. It is not probable, however, that this was Budeč. Later Frankish expeditions are only described very briefly, but no mention is made of mass executions at their hands. Accounts of internal conflicts in tenth-century Bohemia are described almost exclusively in hagiographical literature.

The most probable context for the massacre and other changes at Budeč lies in the wave of violence that reportedly followed the murder of Duke Wenceslas by his brother Boleslav and his retainers at the stronghold of Stará Boleslav in AD 935. According to the tenth-century Latin legend Crescente fide (Emler 1873: 187): “[Boleslavs's retainers] at once made haste to Prague, murdered all his [Wenceslas's] friends and pursued his clerics". Legenda Christiani states that: 


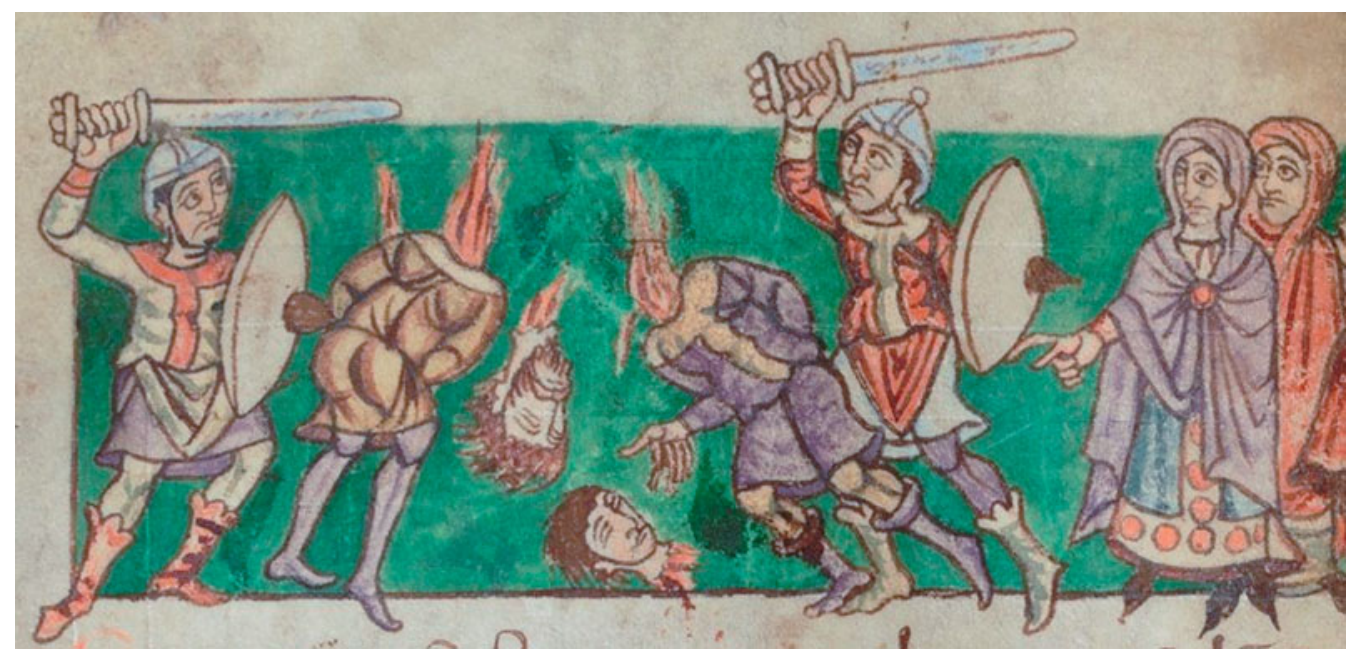

Figure 8. The slaughter of priests attended by their wives in Psalm 78:64, as imagined by the illustrator of the Stuttgart Psalter (Saint-Germain-des-Prés, AD 820-830); (C) Württembergische Landesbibliothek Stuttgart.

[Boleslavs's retainers] wildly rush[ed] to Prague Castle, killing all his [Wenceslas's] friends by various and cruel deaths, drowning their children alive in the depths of the River Vltava [...] there were so many of them that we know neither their number, nor their names" (Ludvíkovský 2012 [1978]: 82).

Neither of the hagiographers name Budeč in this context, but Wenceslas did spend part of his youth there. Retainers loyal to him therefore presumably continued to reside at the stronghold after his accession to ducal power. Boleslav, who seized Prague illegitimately after Wenceslas's murder in $\mathrm{AD}$ 935, could not have retained control without also taking nearby Budeč.

As the legends suggest, the main initiator of the massacres was perhaps not the duke himself, but rather his retainers, who made use of the fratricide to liquidate rival elites. Another massacre recorded at Libice nad Cidlinou, central-east Bohemia, where the noble family of Slavník was exterminated in AD 995, apparently had a similar motivation (Sláma 2000). The elite of the early Bohemian state was evidently composed of several rival groups whose conflicts might sometimes have escalated as far as outright extermination.

\section{Conclusion}

The majority of the individuals found in the mass grave outside of Budeč were sturdy young adult men (20-40 years) who had met violent deaths. Judging from their healed injuries, at least some of them had previous combat experience. Analysis of the distribution of injuries on the skeletons, most probably inflicted by swords, proved that the men did not, or more probably could not, defend themselves from their attackers. Thus, they were either surprised or captured by stratagem. Decapitation has been demonstrated for between 10 and 24 of the victims. The marks of multiple blows suggest that the violence was not 'professionally performed' as part of a formalised execution. Consequently, it is perhaps more appropriately

(C) Antiquity Publications Ltd, 2016 
interpreted as a massacre, although in view of the decapitations, one that might have been staged as a cruel public performance. The bodies of the executed men remained unburied on the surface for an extended time. The deficit of skulls in the mass grave relative to post-cranial remains could indicate that they were removed as trophies or to be displayed as a warning.

The basic characteristics of the mass grave at Budeč appear similar to those of the Ridgeway Hill mass burial, where more than 50 executed men, probably of Scandinavian origin, were buried sometime in the tenth or early eleventh century AD. Unlike those at Budeč, however, they may not have been professional warriors, and were seemingly interred immediately after their execution (cf. Loe et al. 2014). The distribution of injuries at Budeč shows a greater variability in the forms of violence that were experienced.

The massacre at Budeč took place sometime between AD 930 and 990. Although limitations of dating and the lack of a stratigraphic relationship prohibit a direct correlation between the 119 burials in independent graves and those of the mass burial, they are nevertheless dated to roughly the same period (Table 3). The distinct majority of men interred within the mass grave contrasts with the prevalence of women and children in the surrounding burial ground. The most probable explanation is that they belonged to a single group who had originally resided at the stronghold or in its vicinity. Yet, taking into account the size of the Budeč fortress, its garrison must have comprised more than 60 members. The slaughtered men were perhaps mostly professional elite warriors.

In light of current knowledge, we propose a connection between the massacre and the violence following the death of Duke Wenceslas in $\mathrm{AD}$ 935, when the retinue of his brother Boleslav probably took the stronghold by force and dispatched its military garrison. This might also have led to changes in the structure of the acropolis within the stronghold, as well as producing the unusual mortality profile in the burial ground surrounding the mass grave. While more recent conflicts may, in some cases, have resulted in mass graves with much higher numbers, the 60 dead recorded from one particular event at Budeč was a not-insubstantial number for the time. It shows that large-scale extreme violence was not narrative embellishment on the part of the chroniclers, or a product of the imagination of artists (Figure 8 ), but indeed very much a reality.

\section{Acknowledgements}

This paper was developed within the project of the Charles University Research Development Schemes (PRVOUK P12) and with institutional support RVO:67985912. We would like to thank Letty ten Harkel (School of Archaeology, University of Oxford) and both reviewers for their helpful comments.

\section{References}

BACHRACH, D.S. 2013. Henry I's military campaign in archaeological perspective. Early medieval Europe 21: 307-37.

http://dx.doi.org/10.1111/emed.12020

BAKer, J. \& S. BRoOKs. 2013. Beyond the Burghal Hidage: Anglo-Saxon civil defence in the Viking Age. Leiden: Brill.
BARTONíČEK, J. \& J. HeŘT. 2004. Základy klinické anatomie pohybového aparátu. Praha: Maxdorf.

BARTOŠKOVÁ, A. 2010. Budeč: ein bedeutendes Machtzentrum des 'frühen' böhmischen Staates. Zeitschrift für Archäologie des Mittelaters 38: 85-159.

- 2011. Zánik knížecího dvorce na Budči [The demise of the ducal curtis at Budeč]. Archeologické rozhledy 63: 284-306. 
BEREND, N., P. URBAŃCZYK \& P. WISZEWSKI. 2013. Central Europe in the High Middle Ages: Bohemia, Hungary and Poland, c. 900-c. 1300. Cambridge: Cambridge University Press. http://dx.doi.org/10.1017/CBO9780511813795

BLAJEROVÁ, M. 1992. Slovanské kostrové nálezy z Budče-Na Týnici v pohledu antropologa. Archeologické rozhledy 44: 577-92.

BRoOKs, S.T. \& J.M. SuCHEY. 1990. Skeletal age determination based on the os pubis. Human Evolution 5: 227-38. http://dx.doi.org/10.1007/BF02437238

Buikstra, J., D. UbELAKER \& D.A. AFTANDILIAN. 1994. Standards for data collection from human skeletal remains. Fayetteville: Arkansas Archaeological Survey.

CHARVÁT, P. 2010. The emergence of the Bohemian state. Leiden: Brill. http://dx.doi.org/10.1163/ej. 9789004180093.i-245

EMLer, J. 1873. Fontes rerum Bohemicarum, tom 1. Prague: Museum Království Ceského.

Fiorato, V., A. Boylston \& C. KNÜsel. 2000. Blood red roses. The archaeology of a mass grave from the Battle of Towton AD 1461. Oxford: Oxbow.

Hägermann, D. 2010. Karl der Große. Herrscher des Abendlandes. Berlin: Propyläen.

HaLsalL, G. 2003. Warfare and society in the barbarian West, 450-900. London: Routledge.

KalHOUS, D. 2012. Anatomy of a duchy: the political and ecclesiastical structures of early Premyslid Bohemia. Leiden: Brill. http://dx.doi.org/10.1163/9789004229815

KARA, M. 1992. The graves of the armed Scandinavians from the early and middle Viking period in the territory of the first Piast state, in Death and burial: pre-printed papers IV. Medieval Europe 1992: 167-77. York: Medieval Europe.

Kelley, J.O. \& J.L. ANGEL. 1987. Life stresses of slavery. American Journal of Physical Anthropology 74: 199-211. http://dx.doi.org/10.1002/ajpa.1330740208

KJELlströM, A. 2005. A sixteenth-century warrior grave from Uppsala, Sweden: the Battle of Good Friday. International Journal of Osteoarchaeology 15: 23-50. http://dx.doi.org/10.1002/oa.746

Loe, L., A. Boyle, H. WebB \& D. Score. 2014. 'Given to the ground': a Viking age mass grave on Ridgeway Hill, Weymouth. Oxford: Oxford Archaeology.

LOVEJOY, C.O. 1985. Dental wear in the Libben population: its functional pattern and role in the determination of adult skeletal age at death, American Journal of Physical Anthropology 68 47-56.
LuDVíKOvskÝ, J. (ed.). 2012 [1978]. Legenda Christiani. Vita et passio sancti Wenceslai et sancte Ludmile ave eius. Prague: Vyšehrad.

Price, T.D., K.M. Frei, A.S. Dobat, N. Lynnerup \& P. BENNIKE. 2011. Who was in Harold Bluetooth's army? Strontium isotope investigation of the cemetery at the Viking Age fortress at Trelleborg, Denmark. Antiquity 85: 476-89. http://dx.doi.org/10.1017/S0003598X00067880

ReYnOlDS, A. 2009: Anglo-Saxon deviant burial customs. Oxford: Oxford University Press.

Ruff, C.B., B. Holt \& E. Trinkaus. 2006. Who's afraid of the big bad Wolff?: Wolff's law and bone functional adaptation. American Journal of Physical Anthropology 129: 485-98. http://dx.doi.org/10.1002/ajpa.20371

SchmitT, A. 2005. Une nouvelle méthode pour estimer l'âge au décès des adultes à partir de la surface sacro-pelvienne iliaque [A new method to assess adult age at death from the iliac sacro-pelvic surface]. Bulletins et Mémoires de la Société d'Anthropologie de Paris 17: 89-101.

SLÁMA, J. 1988. Střední Čechy v raném strédověku. III. Archeologie o počátcích premyslovského státu [Central Bohemia in the Early Middle Ages. III. Archaeology and the beginning of the Premyslid-dynasty state] (Praehistorica XIV). Praha: Univerzita Karlova.

- 2000. Přemysliden und Slavnikiden, in A. Wieczorek \& H. Hinz (ed.) Europas Mitte um 1000. Beiträge zur Geschichte, Kunst und Archäologie: Band 1: 441-43. Stuttgart: Theiss.

ŠTEFAN, I. 2009: Frühmittelalterliche Sonderbestattungen in Böhmen und Mähren: Archäologie der Randgruppen?

Ethnographisch-archäologische Zeitschrift 50: 139-62.

ŠTeFAN, I. \& I. KRUTina. 2009. Raně středověké sídliště, hromadný hrob a pohřebiště na Budči (poloha Na Týnici). Ke vztahu archeologie a 'událostní historie' [The early medieval settlement, mass grave and burial grounds at Budeč ( $\mathrm{Na}$ Týnici site). Archaeological and 'event history' perspective)]. Památky archeologické 100: 119-212.

STLOUKAL, M. \& L. VYHNÁNEK. 1976. Slované z velkomoravských Mikulčic. Praha: Academia.

STRÁNSKÁ, P. 2009. Raně středověké pohřebiště a Budči (poloha Na Týnici). Antropologická charakteristika, zdravotní stav chrupu [The early medieval Burial Site in Budeč (Na Týnici) Anthropological Description, Dental Health]. Památky archeologické 100: 213-40. 


\section{Ivo Stefan et al.}

VARADZIN, L. 2011. The development of Přemyslid domain strongholds in the heart of Bohemia (a contribution to the discussion), in J. Macháček \& $\zeta$. Ungerman (ed.) Frühgeschichtliche Zentralorte in Mitteleuropa (Studien zur Archäologie Europas 14): 405-10. Bonn: Habelt.

Walrath, D.E, P. Turner \& J. BruzeK. 2004.

Reliability test of the visual assessment of cranial traits for sex determination. American Journal of Physical Anthropology 125: 132-37.

http://dx.doi.org/10.1002/ajpa.10373
WieczoreK, A. \& H. Hinz (ed.). 2000. Europas Mitte um 1000. Katalog. Stuttgart: Theiss.

ZotZ, T. 1999. Cannstatt, Gerichtstag, in Lexikon des Mittelaters, Band II: 1436-37. München: Melzer.

Received: 10 February 2015; Accepted: 6 May 2015; Revised: 1 June 2015

(C) Antiquity Publications Ltd, 2016 